\title{
Diet and lead toxicity
}

\author{
By M. R. Moore, University of Glasgow, Department of Medicine, Gardiner \\ Institute, Western Infirmary, Glasgow GI $6 N T$
}

\section{Introduction}

There is no known biological function for lead and any lead absorbed by man or by animal may be classified as potentially toxic. These toxic effects are many, ranging from morphological damage to tissues at higher concentrations, to lesser biochemical effects at lower concentrations. In biochemical systems lead will generally inhibit enzyme activity and result in clinical effects such as the development of anaemia, which is mediated in part through inhibition of haem biosynthesis. $\mathrm{Pb}$ has been associated with mental retardation in children and with hypertension and renal effects in adults (Moore, 1977). The potentially most hazardous effects to man are upon the central and peripheral nervous systems where the malign effects of $\mathrm{Pb}$ are seldom reversible.

The sources of $\mathrm{Pb}$ are many, but the principal absorptive routes are from the diet, from water that is drunk and used in cooking and from the air that we breathe. There may also be secondary and limited absorption by the percutaneous route (Fig. 1). Following absorption, $\mathrm{Pb}$ is bound principally in bone (greater than $90 \%$ ). This $\mathrm{Pb}$ is fortunately not readily bio-available. The principal source of $\mathrm{Pb}$ exposure is through the diet and therefore any component of the diet that will alter the absorption of $\mathrm{Pb}$, or following absorption, alter the distribution of $\mathrm{Pb}$ within the body, (such as by redistribution from the bone) or which influences the normal rate of excretion of $\mathrm{Pb}$, is potentially hazardous.

\section{Absorption}

Since $\mathrm{Pb}$ must be absorbed to become toxic, the actual rate of absorption and retention is of considerable interest. Most studies to date have examined the effects in laboratory rodents and in general it might be assumed that qualitative effects found in these animals may be extrapolated to man, although quantitatively the effects are quite different. Rats are very much more resistant to the toxic effects of $\mathrm{Pb}$ than man. There is a tenfold difference in the rate of $\mathrm{Pb}$ absorption from the gut between the laboratory rat and man. Rats will only absorb around $1 \%$ of ingested $\mathrm{Pb}$, where man has been shown to absorb in excess of $10 \%$ of an ingested dose (Rabinowitz et al. 1976). In rats and mice absorption of $\mathrm{Pb}$ from the intestine does not appear to be dose-dependent (Gerber \& Wei, 1974; Conrad \& Barton, 1978) until the concentration of $\mathrm{Pb}$ is relatively high. Feeding decreases lead absorption (Garber \& Wei, 1974) and following food restriction, Quarterman et al. (1976) noted that the retention of $\mathrm{Pb}$ was increased although there was not always an increase of the $\mathrm{Pb}$ content of the animal. However, Conrad \& Barton (1978) 


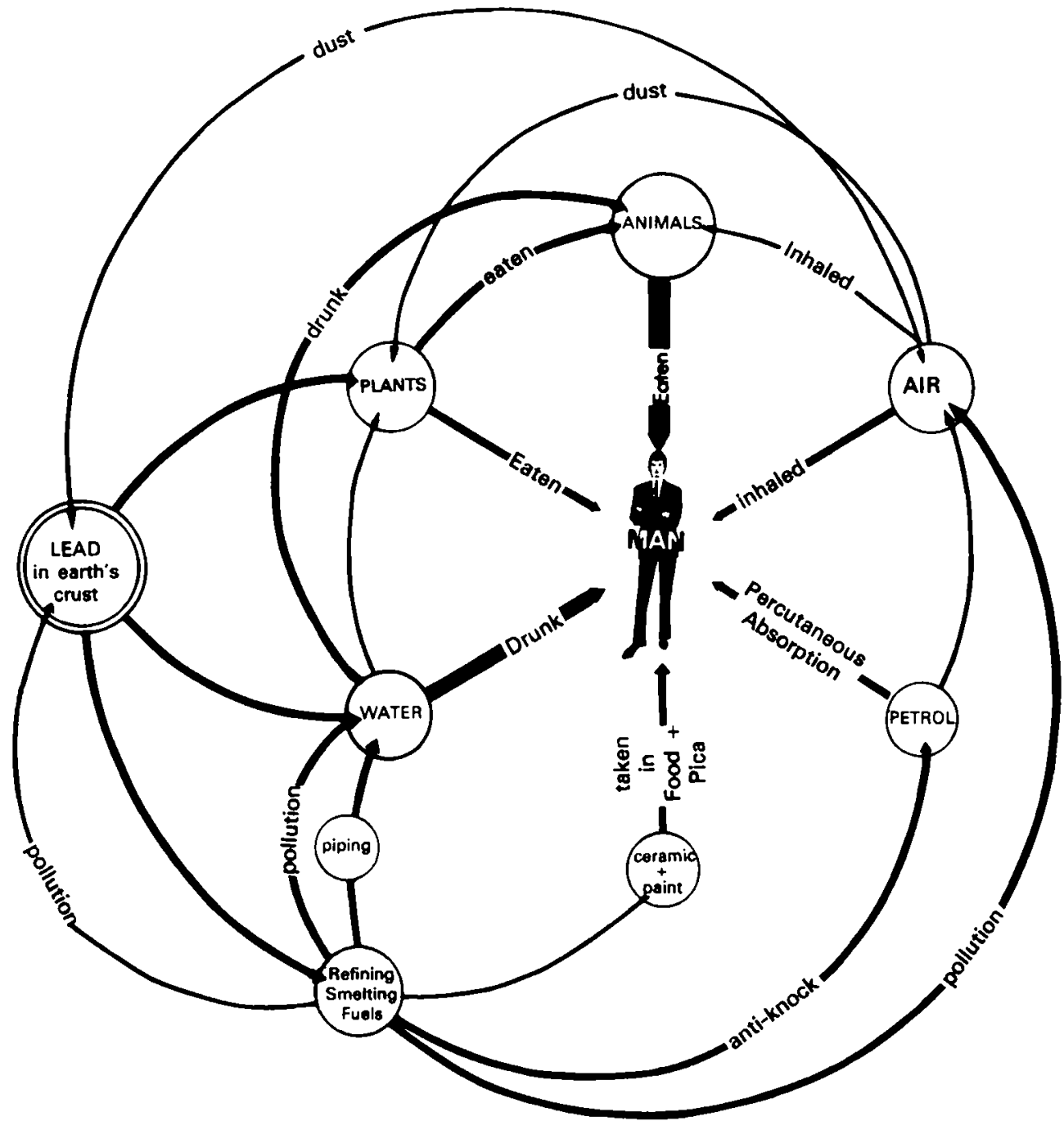

Fig. 1. The various vectors of lead exposure in man. Although other sources may play a variable role in total $\mathrm{Pb}$ exposure, the intake of $\mathrm{Pb}$ in diet is consistently the major source of the body $\mathrm{Pb}$ burden.

found that starvation lowered $\mathrm{Pb}$ absorption and there clearly is the possibility of adaptation of absorptive or excretory processes where consistent administration of high concentrations of $\mathrm{Pb}$ over long time periods will result in maxima of $\mathrm{Pb}$ absorption followed by decreases in the concentrations of $\mathrm{Pb}$ in various tissues (Moore et al. 1974; Morrison et al. 1974; Kelliher et al. 1973). Equally, animals given purified diets show increased susceptibility to $\mathrm{Pb}$ toxicity probably because of increased absorption from such diets (Mylroie et al. 1978). Age will also influence the rate of absorption of $\mathrm{Pb}$ from the gut. Both young rats (Kostial et al. 1971; Forbes \& Reina, 1972; Quarterman \& Morrison, 1978) and human infants 
(Alexander et al. 1973; Zeigler, Edwards et al. 1978) show increased absorption and retention of $\mathrm{Pb}$.

An additional interesting feature of the effect of diet upon absorption arises during the cooking of foods. It is accepted that washing with water will remove topical $\mathrm{Pb}$ from foods such as vegetables. It is not, however, generally known that most foods show a positive uptake of $\mathrm{Pb}$ from aqueous cooking media (Moore et al. 1979). This can markedly alter the quantity of $\mathrm{Pb}$ available for absorption.

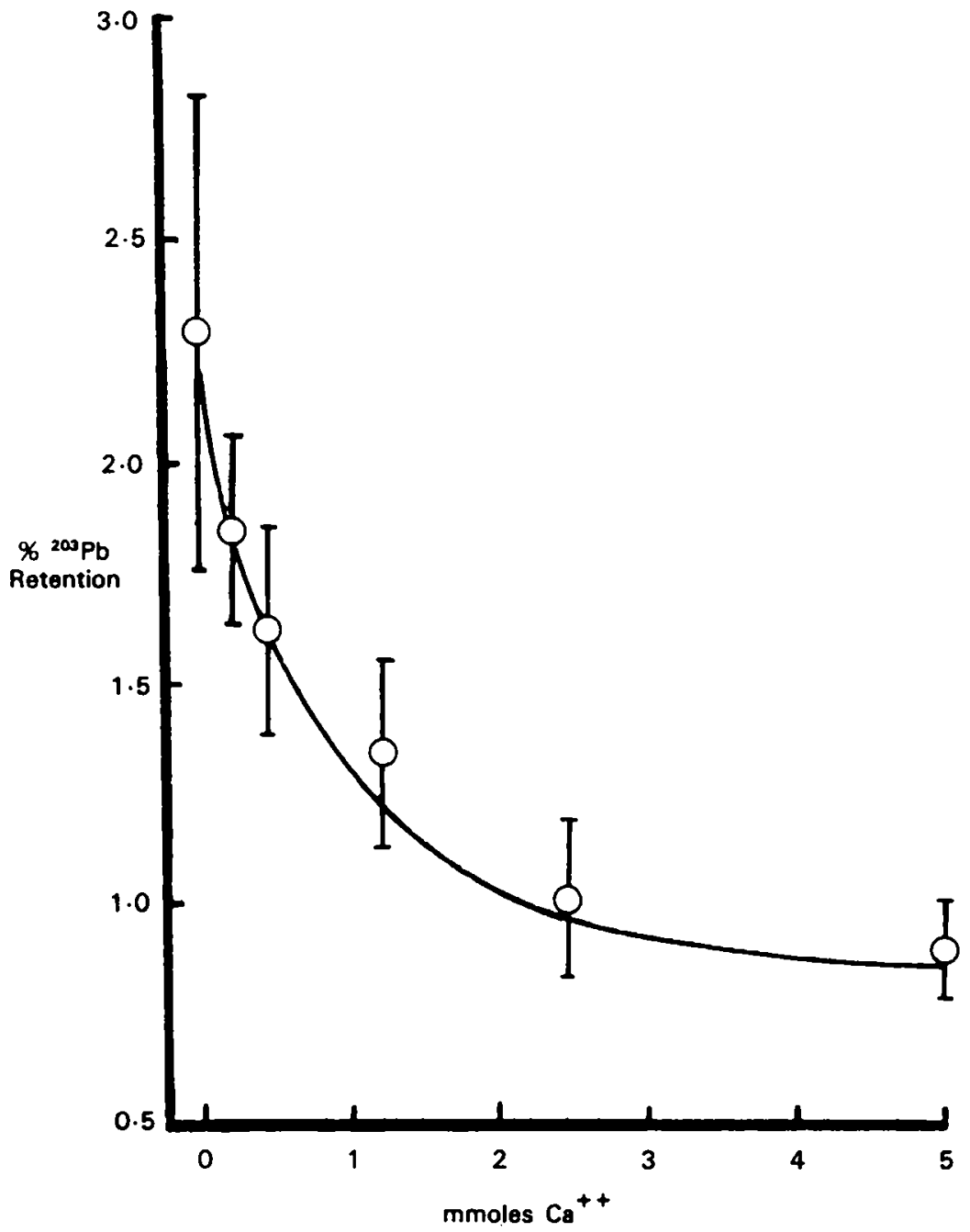

Fig. 2. The influence of varying concentrations of calcium salts (calcium chloride) on the whole body retention of ${ }^{203}$ lead chloride in rats. Six groups of rats were intubated with varying amounts of $\mathrm{CaCl}_{2}$ solution followed after $10 \mathrm{~min}$ with an oral solution of $5 \mu \mathrm{mol}{ }^{203} \mathrm{~Pb} \mathrm{Cl}_{2}(25 \mu \mathrm{Ci})$. Whole body counts were monitored after $120 \mathrm{~h}$. Each point represents the mean \pm SD for each group at $120 \mathrm{~b}$. 
Of all dietary components most likely to influence $\mathrm{Pb}$ absorption, minerals have been most extensively examined. Various studies have shown that the retention of $\mathrm{Pb}$ varies inversely with dietary calcium content (Fig. 2). There is a residual quantity of $\mathrm{Pb}$ that may be absorbed which is unaffected by the concentration of $\mathrm{Ca}$ within the gut. This would suggest that there are two mechanisms for transport of $\mathrm{Pb}$ from the lumen of the gastrointestinal tract across the gut wall, only one of which is influenced by $\mathrm{Ca}$ (Meredith et al. 1977). Equally, systemic Ca concentrations do not appear to influence $\mathrm{Pb}$ retention (Quarterman \& Morrison, 1974; Meredith et al. 1977). It has been postulated that $\mathrm{Ca}$ and $\mathrm{Pb}$ share binding sites on absorptive protein to cause this effect (Barton et al. 1978a) and indeed that iron will act similarly (Barton et al. $1978 b$ ). It has indeed been suggested that there may be a basis in mineral deficiency for the production of $\mathrm{Pb}$ pica in infants (Snowdon, 1976). Gruden et al. (1974) found that $\mathrm{Pb}$ inhibited the transport of $\mathrm{Ca}$ across the duodenal wall of rats in vitro. Like calcium, most other minerals, such as $\mathrm{Fe}$ (Six \& Goyer, 1972), zinc (Conrad \& Barton, 1978), copper (Klauder \& Petering, 1975) and magnesium (Fine et al. 1976), will diminish $\mathrm{Pb}$ absorption from the gut. Unlike $\mathrm{Ca}, \mathrm{Fe}$ absorption is apparently not influenced by increased $\mathrm{Pb}$ concentrations (Dobbins et al. 1978).

The mode of action of $\mathrm{Ca}$ on $\mathrm{Pb}$ absorption is not clear. Studies using everted intestinal sack preparations have suggested that $\mathrm{Pb}$ transport into the serosal compartment is related to water movement. Ionic $\mathrm{Pb}$ utilizes the extra-cellular route to transverse the intestinal barrier. Results have suggested that any process which opens up the tight junctions between cells will increase absorption. (Blair et al. 1979; Coleman et al. 1978). Factors known to cause such changes are depleted concentrations of $\mathrm{Ca}^{2+}$ and increased acidity. These studies have also shown that $\mathrm{Pb}$ interacts with tissue phosphate ions which removes the $\mathrm{Pb}$ from the available transport pool. Thus $\mathrm{Pb}$ transport across the intestinal wall has two separate rate processes, one being the binding of the $\mathrm{Pb}$ to the cell surface and the second the transport of $\mathrm{Pb}$ across the intestinal membrane and subsequent accumulation in the serosal compartment.

Vitamin $\mathrm{D}$ administration influences $\mathrm{Pb}$ uptake in a manner similar to that it exercises on the absorption of $\mathrm{Ca}$. Thus, in situations where high vitamin $\mathrm{D}$ concentrations are found, there is enhancement of $\mathrm{Pb}$ absorption (Smith et al. 1978). Surprisingly, however, it has been found that in $\mathrm{Pb}$-burdened children a relative vitamin $\mathrm{D}$ deficiency rather than excess is associated with high blood lead levels (Sorrell et al. 1977).

There is then a catalogue of substances that might influence the absorption of $\mathrm{Pb}$ by various means. In general, substances influencing the intestinal barrier (such as ethanol) will increase $\mathrm{Pb}$ absorption (Mahaffey et al. 1974). Equally, substances that increase the solubility of $\mathrm{Pb}$ will also increase its absorption. Examples of this are by acidification, such as ascorbic or citric acid or combination with other compounds such as amino acids (Conrad \& Barton, 1978) or chelating agents (Jugo et al. 1975). Tannic acid has been reported to exert a protective effect upon 
animals given dietary $\mathrm{Pb}$ (Peaslee \& Einhellig, 1977) which may well be related to its affinity to bind heavy metals.

Of other major dietary components likely to influence absorption, carbohydrates would appear to have little effect, whilst there are large increases in $\mathrm{Pb}$ uptake with increasing dietary fat content (Barltrop \& Khoo, 1976). This increase with increasing fat content, has been associated with increased concentration of phospholipids and indeed, ultimately, with the possible stimulation of bile flow which will add phospholipids and bile salts to the gut lumen content (Quarterman et al. 1977). The effects of dietary protein have been shown to be complex but in general lowering of dietary protein lowers the uptake of $\mathrm{Pb}$. This effect is screened by apparent increases in $\mathrm{Pb}$ absorption due to dietary restriction, which means that growth rate and $\mathrm{Pb}$ retention are inversely related (Quarterman et al. 1978).

\section{Toxicity following absorption}

In an analysis of the toxic interactions of $\mathrm{Pb}$ with other minerals on the haematological system, Thawley et al. (1977) found that toxic concentrations of other metals such as $\mathrm{Zn}$ or $\mathrm{Cd}$ caused a marked reduction in other toxic effects of $\mathrm{Pb}$, such as reticulocytosis, and indeed administration of $\mathrm{Zn}_{\mathrm{n}}$ caused a diminution of urinary delta-aminolaevulinic acid concentrations. Of all the effects of $\mathrm{Pb}$ upon biological systems, those on the haem biosynthetic pathway, and particularly upon the enzyme delta-aminolaevulinic acid (ALA) dehydratase, have been studied most extensively. Increasing concentrations of $\mathrm{Zn}$ decreases the toxic effects of $\mathrm{Pb}$ upon this enzyme (Meredith \& Moore, 1978). Like $\mathrm{Zn}$, ethanol exerts an antagonistic effect on ALA dehydratase, where raised ethanol concentrations reverse the decreases in enzyme activity caused by $\mathrm{Pb}$ (Moore, 1975). It has also been noted that high dietary $\mathrm{Zn}$ concentrations will reduce $\mathrm{Pb}$ levels in tissues, all of which would suggest that there is a protective role for $\mathrm{Zn}$ in $\mathrm{Pb}$ toxicity (Cerklewski \& Forbes, 1976; El-Gazzar et al. 1978). Similar effects have been observed for aluminium, although in this case it is not certain that the diminution of effect occurs at concentrations within physiological levels (Meredith et al. 1977). Another element exhibiting a similar antagonistic toxic effect is selenium. Selenium and lead together, both at toxic concentrations, were found to result in normal activities of ALA dehydratase and cytochrome P-450 activity in rats, in which the activities of both compounds were depressed in animals treated either with $\mathrm{Se}$ or $\mathrm{Pb}$ alone (Rastogi et al. 1976).

The neurotoxic effects of $\mathrm{Pb}$ may be attributed to various aspects of $\mathrm{Pb}$ based biochemical alterations of physiological pathways. Amongst these, $\delta$ aminolaevulinic acid has been shown to have neuroactive effects. (Moore \& Meredith, 1976). In consequence, alteration of $\mathrm{Zn}$ availability and therefore of ALA dehydratase activity, could markedly affect the synthesis of ALA and therefore change its neurotoxic action. Similarly, Ca plays a central role in nerve transmission and $\mathrm{Pb}$ has been postulated to act at synaptic sites by increasing the $\mathrm{Ca}$ flux (Silbergeld \& Adler, 1978). Again, the availability of $\mathrm{Ca}$ with changes in the $\mathrm{Pb}-\mathrm{Ca}$ interaction must influence this effect. 
A positive correlation has been reported between concentrations of vitamin $E$ and tissue $\mathrm{Pb}$ concentrations (Sleet \& Soares, 1978). The effects of other vitamins and hormones cannot be neglected at this stage. Increased levels of $\mathrm{Pb}$ diminish thiamine content in rat liver (Tokarski \& Reio, 1978), whilst other substances, such as ascorbic acid and other $\mathrm{Pb}$-binding agents, (e.g. cysteine and methionine) may decrease $\mathrm{Pb}$ toxicity by increasing its excretion (MacNiff et al. 1978). In the circumstances where vitamin $\mathrm{D}$ will increase $\mathrm{Pb}$ absorption, it is also true that vitamin $\mathrm{D}$ will lower blood $\mathrm{Pb}$ concentrations in animals with established $\mathrm{Pb}$ poisoning. This is also associated with a decreased loss of $\mathrm{Pb}$ from bone (Sobel \& Burger, 1955). Similarly, citric acid will decrease $\mathrm{Pb}$ toxicity by increasing its excretion in the urine. The possibility therefore exists that the presence of other compounds in the body will alter the over-all distribution of $\mathrm{Pb}$ within the body.

In studies of parathyroid hormone in rats, it was found that there was an increase in the renal accumulation of $\mathrm{Pb}$ and therefore presumably in the potential toxic effects of $\mathrm{Pb}$ on the kidney (Mouw et al. 1978). These effects were attributed to increased formation of insoluble $\mathrm{Pb}$ phosphate in renal cells following mitochondrial breakdown although it might also have been attributed to changes in tubular reabsorption in the kidney. These effects on the kidney are analogous to those found by Quarterman et al. (1977) who found increased $\mathrm{Pb}$ content in the kidneys of castrated rams, but surprisingly, a greater mortality in the normal rams than in the castrates. The result implied, together with the observations of others, that hormonal effects will influence the excretion of $\mathrm{Pb}$ (Alcroft \& Blaxter, 1950; Kostial et al. 1974). In the same experiments, Quarterman et al. (1977) found diminished toxic effects of dietary $\mathrm{Pb}$ following sulphate addition to the diet of lambs. They attributed this effect to the formation of sulphydryl compounds during rumen digestion which, by binding $\mathrm{Pb}$, lowered its retention.

\section{Excretion}

From what has been said before various dietary components will considerably alter $\mathrm{Pb}$ excretion, for example, increased $\mathrm{Ca}$ levels decrease the rate of loss of $\mathrm{Pb}$ (Quarterman et al. 1978), although $\mathrm{Fe}$ apparently does not influence excretion (Barton et al. 1978). Chelating agents would appear to play a central role by increasing $\mathrm{Pb}$ excretion. These are frequently used as food additives (Furia, 1968). Amino acids, such as methionine and cysteine, will also facilitate the renal excretion of $\mathrm{Pb}$. Therapeutically, penicillamine has been used for the treatment of $\mathrm{Pb}$ poisoning (Goldberg et al. 1963). This functions by increasing the urinary excretion of $\mathrm{Pb}$ as the chelated penicillamine complex. Although some chelating agents such as ethylenediaminotetraacetic acid are poorly absorbed from the intestine, if these are given to man or to animals by injection they rapidly result in the loss of $\mathrm{Pb}$ in the urine. Such an enhancement of urinary excretion of $\mathrm{Pb}$ is common to all chelating agents (Graziano et al. 1978). The effects of acidic compounds such as citric acid or ascorbic acid are more equivocal. In both cases the rate of metabolism may be so great following absorption as to have little effect on the subsequent urinary excretion of $\mathrm{Pb}$. It has been shown, however, that 
blockage of the citric acid cycle with mono fluoroacetic acid allowed modest doses of sodium citrate to provide animals with protection against $\mathrm{Pb}$ poisoning (Schubert \& Lindenbaum, 1960).

\section{Overview}

The preceding review has clearly demonstrated the difficulty of assessing potential effects of certain diets on not only the absorption and excretion of $\mathrm{Pb}$, but also upon the various effects of the dietary components following absorption and prior to excretion. Even when viewed individually it is not always clear whether the net effect of a single dietary component will be beneficial or otherwise. $\mathrm{Ca}$, which would appear to be a useful compound in the prophylaxis of $\mathrm{Pb}$ poisoning, demonstrated this. In one study, Moore et al. (1978) showed that the use of calcium glycerophosphate as a prophylactic agent against $\mathrm{Pb}$ absorption produced only small, although significant, effects on the blood $\mathrm{Pb}$ status of a group of lead workers. The whole problem is perhaps best exemplified by the example of milk, the effects of which are well summarized by Stephens \& Waldron (1975). In millk there are a number of different components, some of which will increase and some decrease $\mathrm{Pb}$ absorption. Some components which raise or lower toxic effects following absorption and finally some which will increase and some which will cause a diminution in the excretion of the absorbed $\mathrm{Pb}$. The over-all conclusion was that the net effect would be an enhancement of $\mathrm{Pb}$ absorption by mill but it is by no means clear that such a conclusion can be made in all circumstances since other studies have shown that malnutrition will increase $\mathrm{Pb}$ absorption and in consequence a valuable food such as milk could potentially alter this. One may therefore conclude that only in circumstances where a single dietary component is found in great excess or in great deficiency will one be able to divine the likely outcome in terms of $\mathrm{Pb}$ toxicity.

\section{REFERENCES}

Alexander, F. W., Clayton, B. E. \& Delves, H. T. (1974). Q. $9 l$ Med. 43, 89.

Allcroft, R. \& Blaxter, K. L. (1950). F. comp. Path. Ther. 60, 209.

Barltrop, D. \& Khoo, H. E. (1976). Sci. Total Environ. 6, 265.

Barton, J. C., Conrad, M. E., Harrison, L. \& Nuby, S. (1978a). F. Lab. clin. Med. 91, 366.

Barton, J. C., Conrad, M. E., Nuby, S. \& Harrison, L. (r978b). F. Lab. clin. Med. 92, 536.

Blair, J. A., Coleman, I. P. L. \& Hiburn, M. E. J. Physiol. Lond. (1979). 286, 343.

Blake, K. C. H. (1976). Environ. Res. II, I.

Certlewski, F. L. \& Forbes, R. M. (1976). भ. Nutr. 106, 689.

Coteman, I. P. L., Hilburn, M. E. \& Blair, J. A. Biochem. Soc. Trans. (1978). 6, 915.

Conrad, M. E. \& Barton, J. C. (1978). Gastroenterology 74, 731.

Dobbins, A., Johnson, D. R. \& Nathan, P. (1978). F. Toxic. Envirom Hth 4, 541 .

El-Gazzar, R M., Finelli, V. N., Boiano, J. \& Petering, H. G. (1978). Toxic. Lett. I, 227.

Fine, B. P., Barth, A., Sheffet, A. \& Lavenhar, A. (1976). Environ. Res. 12, 224.

Forbes, G. B. \& Reina, J. C. (1972). F. Nutr. ro2, 647.

Furia, T. E. (1968). Handbook of food additives, pp. 262-266, 289-312. Cleveland Ohio: Chemical Rubber Publishing Co.

Garber, B. T. \& Wei, E. (1974). Toxic. appl. Pharmac. 27, 685.

Goldberg, A., Smith, J. A. \& Lochhead, A. (1963). Br. med. f. ii, 1270.

Graziano, J. H., Leong, J. K. \& Friedheim, E. (1978). F. Pharmac. exp. Ther. 206, 696.

Gruden, N., Stantic, M. \& Buben, B. (1974). Environ. Res. 8, 203.

Jugo, S., Maljkovic, T. \& Kostial, K. (I975). Toxic. appl. Pharmac. 34, 259. 
Kelliher, D. J., Hilliard, E. P., Poole, D. B. R. \& Collins, J. D. (1973). Irish F. Agric. Res. 12, 61.

Klauder, D. S. \& Petering, H. G. (1975). Environ. Hlth Perspect. 12, 77.

Kostial, K., Maljkovic, T. \& Jugo, S. (1974). Archs Toxic. 31, 265.

Kostial, K., Simonovic, I. \& Pisonic, M. (1971). Environ. Res. 4, 360.

Mahaffey, K. R., Goyer, R. A. \& Wilson, M. H. (1974). Archs Environ. Hlth 28, 217.

McNiff, E. F., Cheng, L. K., Woodfield, H. C. \& Fung, H. L. (1978). Res. Commum. Chem. Path. Pharmac. 20, 131 .

Meredith, P. A. \& Moore, M. R. (1978). Biochem. Soc. Trans. 6, 760.

Meredith, P. A., Moore, M. R. \& Goldberg, A. (1977). Enxyme 22, 22.

Meredith, P. A., Moore, M. R. \& Goldberg, A. (1977). Biochem. F. 166, 531.

Moore, M. R. (1975). In Proc. Int. Symp. Recent Advances in the Assessment of the Health Effects of Environmental Pollution, C.E.C. Luxembourg, p. IIg.

Moore, M. R. (1977). Sci. Total Environ. 7, 109.

Moore, M. R., Goldberg, A., Carr, K., Toner, P. \& Lawrie, T. V. D. (1975). Clin. Sci. Mol. Med. 49, 337.

Moore, M. R., Hughes, M. A. \& Goldberg, D. Int. Archs Occup. Environ. Hlth (In the Press).

Moore, M. R. \& Meredith, P. A. (1976). In Trace Substances in Environmental Health X., p. $3_{3}$ [D. D. Hemphill, editor]. Columbia: University of Missouri.

Moore, M. R., Meredith, P. A., Campbell, B. C., Goldberg, A. \& Baird, A. (1978). Drugs Exptl Clin. Res. 4, 17.

Morrison, J. N., Quarterman, J. \& Humphries, W. R. (1974). Proc. Nutr. Soc. 33, 88A.

Mouw, D. R., Wagner, J. G., Kalitis, K., Vander, A. J. \& Mayor, G. H. (1978). Enoiron. Res. I5, 20.

Mylroie, A. A., Moore, L., Olyai, B. \& Anderson, M. (1978). Environ. Res. 15, 57.

Pesslee, M. H. \& Einhellig. F. A. (1977). Experentia 33, 1206.

Quarterman, J., Humphries, W. R. \& Morrison, J. N. (1976). Proc. Nutr. Sac. 35, 34-35A.

Quarterman, J. \& Morrison, E. (1978). Environ. Res. 17, 78.

Quarterman, J. \& Morrison, J. N. (1974). Br. F. Nutr. 34, 351.

Quarterman, J., Morrison, J. N. \& Humphries, W. R. (1976). Environ. Res. 12, 180.

Quarterman, J., Morrison, J. N. \& Humphries, W. R. (1977). Proc. Nutr. Soc. 36, 103 A.

Quarterman, J., Morrison, J. N., Humphries, W. R. \& Mills, C. F. (1977). F. comp. Path. 87, 405.

Quarterman, J., Morrison, E., Morrison, J. N. \& Humphries, W. R. (1978). Envirom. Res. 17, 68.

Rabinowitz, M. B., Wetherill, G. W. \& Kopple, J. D. (1976). F. elin. Invest. 58, 260.

Rastogi, S. C., Clausen, J. \& Srivastava, K. C. (I976). Toxicology 6, 377.

Schubert, J. \& Lindenbaum, A. (1960). In Metal Binding in Medicine. [J. J. Seven and L. A. Johnson, editors]. Philadelphia: Lippincot.

Silbergeld, E. K. \& Adler, H. S. (1978). Brain. Res. 148, 451.

Six, K. M. \& Goyer, R. A. (1972). F. Lab. clin. Med. 79, 128.

Sleet, R. B. \& Soares, J. H. (1978). Proc. West. Pharmac. Soc. 21, 481.

Smith, C. M., Deluca, H. F., Tanaka, Y. \& Mahaffey, K. R. (1978). F. Nutr. 108, 843.

Snowdon, C. T. (1977). Physiol. Behav. 18, 885.

Sobel, A. E. \& Burger, M. (1955). J. biol. Chem. 212, ro5.

Sorrell, M., Rosen, J. F. \& Roginsky, M. (1977). Archs env. Hlth 31, 160.

Stephens, R. \& Waldron, H. A. (1975). Fd Cosmet. Toxic. 13, 555.

Thawley, D. G., Willoughby, R. A., McSherry, B. J., Macleod, G. K., Mackay, K. H. \& Mitchell, W. R. (1977). Env. Res. 14, 463 .

Tokarsti, E. \& Reid, L. (1978). Acta Chem. Scand. B. 32, 375.

Zeigler, E. E., Edwards, B. B., Jensen, R. L., Mahaffey, K. R. \& Fomon, S. J. (1978). Pediat. Res. 12, 29. 